\title{
Causes of Conflicts and Disputes in Construction Projects
}

\author{
Anita Rauzana \\ Department of Civil Engineering, Syiah Kuala University, Jl. SyechAbdurRauf, Banda Aceh, Aceh Province, \\ Indonesia
}

\begin{abstract}
In the implementation of the project, all parties involved expect the project can be completed in accordance with the expected goals. The expected goals, among others, order to the project was completed on time, not exceeding set budget and quality is met. Constraints in the implementation of the project will occur if the project objectives are not achieved properly. In the implementation of the projectmany conflicts or disputes between the elements involved in the implementation of the project. The purpose of this study was to identify the factors of conflict on the construction project.

Keywords: conflict, dispute, success, construction projects, contractors
\end{abstract}

\section{Introduction}

Constraints in the implementation of the project will appear when the project objectives are not achieved properly. Factor of conflicts or disputes between the elements involved in the project must be managed properly in order to avoid losses. Conflict is the condition of the occurrence of the mismatch between the values or goals to be achieved, both in the individual and in relation to others. Many factors can lead to conflict, including the factor of owners, contractors, consultants, project scope, human resources, contracts and specifications, and external. These factors affect the efficiency and productivity of work, so that it can disturb the implementation of the project.

Construction is a project-based activity that requires endeavors from multiple parties among numerous organizations, each with their own interests to pursue through the implementation of a project (Dulaimi et al. 2003). This complexity, combined with the enormous variety of unforeseen situations that can emerge during a construction project, makes conflict unavoidable (Yiu and Cheung 2006; Acharya et al. 2006). Conflicts between the two main parties in a construction project owners and contractors are the most common. The causes of these specific conflicts are numerous [often including, e.g., ambiguous contract terms, late supply of material and equipment, changed conditions, poor communications, labor disputes, limited resources, inadequate design, and force majeure events (Harmon 2003)], yet they must be settled because unresolved conflicts can lead to claims and disputes, whichundermine the project, cause immense financial harm, and even result in costly litigation (Kumaraswamy 1997; Cheung and Yiu 2006).

\section{Construction Project}

The construction industry is a complex and competitive environment in which participants with different views, talents and levels of knowledge of the construction process work together. In this complex environment, participants from various professions, each has its own goals and each expects to make the most of its own benefits. The increase in the number of participants of different cultural background in the construction value chain means more business interactions and arguments, whether contractual or social, resulting in an increase in the number of construction disputes (Kumaraswamy and Yogeswaran, 1998).There are confusion among construction professionals about the differences between conflict and dispute, and these terms have been used interchangeably especially in the construction industry (Acharya et al., 2006). However, according to Fenn et al. (1997) conflict and dispute are two distinct notations. Conflict exists wherever there is incompatibility of interest. Conflict can be managed, possibly to the extent of preventing a dispute resulting from the conflict. On the other hand, disputes are one of the main factors which prevent the successfully completion of the construction project. Disputes are associated with distinct justiciable issues and require resolution such as mediation, negotiation arbitration, etc.

Suharto (2001), noted that the project can be interpreted as a temporary activity that took place within a limited period, with the allocation of limited resources.According to Dipohusodo (1995), the project is an effort that mobilizes resources, organized to achieve the objectives, and expectations of particular importance and must be completed within a limited period of time in accordance with the agreement.The series of activities in the construction project begins with the an idea that comes from the need and proceed with a study of the possibility of its creation. Then conductedthe preliminary design, detailed design, procurement of resources, construction on the site that has been provided, and maintenance of buildings until the handover of the building to the project owner. 


\subsection{Project management}

According to Suharto (2001), project management can be defined as planning, organizing, directing, controlling of project resources, to achieve short-term goals that have been determined. Project management using an approach and hierarchical system of vertical and horizontal. Objective of the project is composed of elements of cost, quality, and time. The third objective of the project is tripleconstraintsare as follows.

1. The cost of the project must be completed at a cost that does not exceed the budget.

2. Quality, product or output of the project must meet the required specifications and criteria.

3. The time, the project must be done in accordance with the period and the end date specified.

\subsection{Project implementation organization}

According to Dipohusodo (1995), the organization is indispensable for the smooth implementation of the project at the planning and implementation of the project. Organization is a facility that allows people to work together effectively to achieve a purpose that is more clear and focused. In the implementation of a project there are elements of implementation and each has the duty and authority in accordance with his position. Organizational structures in a project need to know to explain the relationship of duty, responsibilities and authority of individuals and groups. In the implementation of the project, there are several elements in the project, namely owner, consultants and contractors. Working relations elements of the project are as follows:

1. The working relationship between the owner and the consultant is a contractual relationship that poured in the agreement Working.

2. The working relationship between the owner and the contractor is a contractual relationship that poured in the agreement Working.

3. The working relationship between the consultant and contractor is functional relationships in performing their duties and responsibilities of each as been stated in the implementation of the document.

\section{Causes of Conflicts and Disputes}

According Suharto (2001), the conflict can be defined as dispute between elements or the opposite thoughts in the project. Although the conflict in the project can be blocking the achievement of one of the parties, but the advantage is as follows:

1. Conflict can provide information and new ideas that ultimately improve thequality of decision-making.

2. Conflict can force the parties involved to think and reconsider his view.

3. Conflict can lead to problems that had been buried become the open and enablethe leadership assist in finding the best solution for the project.

4. Conflict can teach existence mutual understanding and respect for other opinions.

Conflicts can be interpreted a disagreement between two or more members of organizations or groups within the organization that arise because they have to use scarce resources jointly, or carry out activities together, or have the status, goals, values, and perceptions is different (Ranupandoyo and Husnan1995).Leung et al. $(2002,2005)$ partially verified the positive impacts of conflict on construction projects by respectively using case study and questionnaire survey to testify the relationship between distinctive conflict types and participants' satisfaction. They found that a suitable level of conflict-especially task conflict-can indeed improve participants' satisfaction up to a certain point at which diminishing begins. Jehn and Bendersky (2003) warned that conflict impacts appear to diverge when observing different indicators (i.e., objective or subjective) of organization effectiveness, however. It is thus concluded that participants' satisfaction (a subjective criterion) cannot be directly generalized to describe objective performance criteria such as cost, schedule, and project quality (Maloney 1990).

\subsection{Factor of conflict in construction projects}

In the construction industry, since differences in perceptions among the participants of the projects, conflicts are inevitable. If conflicts are not well managed, they are quickly turn into disputes. Disputes are one of the main factors which prevent the successfully completion of the construction project. Thus, it is important to be aware of the causes of disputes in order to complete the construction project in the desired time, budget and quality.

Susila (2012) found in a construction project, on the one hand the contractor's attention is in the completion of the project in accordance with specified schedule and attempt to make financial gain, while on the other hand the owner needs excellent facilitiesat economical prices. The purpose of each party seems contradictory in achieving their goals, such circumstances could lead to conflict. The causes of the conflict can be caused by owner, consultants, contractors, contracts and specifications, human resources, and project conditions. 
The complexity of the work,limited time, the amount of resources used, and many things that affect the process of the construction (Susila 2012). If these constraints are not addressed immediately then it can result in losses and will lead to conflict. Factor of conflicts at the implementation stage occurs when stated in the contract does not according to the implemented in the field. Factors that cause conflicts in construction projects based on previous research can be seen as follows:

Table 1.1Factors ofconflict and disputes in construction projects

\begin{tabular}{|c|c|c|}
\hline Variables & Indicators & Authors \\
\hline \multirow{4}{*}{ Owner } & Failure of respond to issues in a timely & $\begin{array}{l}\text { Fenn, Lowe and } \\
\text { Speck(1997) }\end{array}$ \\
\hline & Lack of communication among the team members & $\begin{array}{l}\text { Fenn, Lowe and } \\
\text { Speck }(1997\end{array}$ \\
\hline & The mechanism is not clear in providing information & $\begin{array}{l}\text { Fenn, Lowe and } \\
\text { Speck }(1997\end{array}$ \\
\hline & Poor management, control and coordination & $\begin{array}{l}\text { Fenn, Lowe and } \\
\text { Speck(1997 }\end{array}$ \\
\hline \multirow{12}{*}{ Consultant } & Failure of to determine responsibility in accordance with the contract & Hall(2002) \\
\hline & Estimation error & Hall(2002) \\
\hline & Delayed in providing information & Hall (2002) \\
\hline & Design errors and specifications & Hall $(2002)$ \\
\hline & Pictures and specifications are incomplete & Hall(2002) \\
\hline & Calculation of incorrect work progress & Kissiedu(2009) \\
\hline & Lack of experience of consultants & $\begin{array}{l}\text { Fenn, Lowe and } \\
\text { Speck }(1997\end{array}$ \\
\hline & Lack of contractor management, supervision, and coordination & Carmicheal(2002) \\
\hline & Delay of jobs & Carmicheal(2002) \\
\hline & Failure ofplan and implement change of work & Carmicheal(2002) \\
\hline & $\begin{array}{l}\text { The failure to understand the price of the work or the offer price } \\
\text { correctly }\end{array}$ & Carmicheal(2002) \\
\hline & Lack of understanding of the existing agreement in the contract & Carmicheal(2002) \\
\hline \multirow{5}{*}{$\begin{array}{l}\text { Contracts } \\
\text { specifications }\end{array}$} & $\begin{array}{l}\text { Employment contracts and the complete lack of construction } \\
\text { documents }\end{array}$ & $\begin{array}{l}\text { Poerdiyatmono } \\
(2007)\end{array}$ \\
\hline & The lack of clarity of document the distribution of workflow & $\begin{array}{l}\text { Poerdiyatmono } \\
(2007)\end{array}$ \\
\hline & There is a confusing of terms in the contract documents & $\begin{array}{l}\text { Poerdiyatmono } \\
(2007)\end{array}$ \\
\hline & $\begin{array}{l}\text { There are terms that can cause a double meaning in the contract } \\
\text { documents }\end{array}$ & $\begin{array}{l}\text { Poerdiyatmono } \\
(2007)\end{array}$ \\
\hline & $\begin{array}{l}\text { The big difference in understanding of contracts in foreign languages } \\
\text { with the same contract and the Indonesian language }\end{array}$ & Poerdiyatmono (2007) \\
\hline
\end{tabular}

\subsection{Conflict management}

Ock and Han (2003), states that the conflict management in addressing the problem of conflict with several methods, as follows :

1. Force

Impose one's views at the expense of the strength of another.

2. Smoothing

Minimize the differences and emphasize togetherness to issues of conflict.

3. Withdrawing

Withdrawing from the real contradictions and conflict situations.

4. Compromise

Consider the various issues, bargaining, and look for ways of settlement or that bring satisfaction to the parties involved in the conflict.

5. Problem solving

Regard to theconflict as a problem to be solved rather than a war to be won, in order to achieve satisfaction along with maintaining relationships and interests conflict. Government Regulation on regulatory changes to Government Regulation of Construction Services Implementation ofSection 49, states that the settlement of disputes in the implementation of construction services out of court can be done in the following way:

1. Completion by both parties in the form of consultation and negotiation

2. Third parties, namely:

a. Mediation appointed by the parties or alternative dispute resolution institutions.

b. Conciliation.

c. Arbitration institutions 


\subsection{The success of projects}

\section{Aspect of costs}

Shah (2004) states that to measure the success of the project in terms of aspects as follows :

a. In accordance with the contract documents and agreements;

b. The project owner agrees and make payment until the work is completed;

c. No progress billing owed; and

d. Obtain the positive benefits, including benefits for the company.

\section{Aspect of quality}

a. In accordance with the technical specifications of the contract documents andagreements;

b. The project owner agreed and accept the project unconditionally;

c. No penalty or complain about the quality of work of the project;

d. Occupational health and safety implemented properly;

e. All parties related to the implementation are satisfied; and

f. Getting a certificate of completion.

\section{Aspect of time}

a. Project completed on time, or according to the work schedule in the contract documents;

b. The project owner agreed and accepts the completion of part or all of the work;

c. No complaints about the implementation progress related to completion of the work.

\section{Conclusions}

The strategy of conflict resolution on the project is by respond to problems in a timely manner, creating good communication among project teams, creating a clear mechanism, creating management and good supervision. The conflict shall be resolved in an appropriate manner to minimize contagion to the efforts of the achievementof the project target.The current dominant theory is the interactionism view that believes that conflict can be constructive in organizations under certain circumstances (Robbins and Judge 2009). There are five techniques that are generally used in resolving conflicts are:

1. Withdraw / Avoid. Techniques for resolving conflict in a way to delay or avoid situations of potential conflict would occur. Avoid or delay the settlement of the conflict in order to do a better preparation, or expect to be completed by others.

2. Smooth / Accomodate. Technique of resolve conflict with an emphasis to the area of the level of agreement.

3. Compromise / Reconcile. Techniques for resolving of conflict by seeking solutions that provide a level of satisfaction to all parties to temporarily or partially resolve the conflict. This approach is also called the "give and take".

4. Force / Direct. Techniques for resolving conflict based on the dominance of one party without regard to the other party. Usually based on the authority and power that the parties resolve the conflict. Also known by the win-lose approach.

5. Collaborate / Problem Solve. Techniques for resolving of conflict by combining multiple the views and from several different perspectives. Requires behavior of co-operative and open dialogue to get a consensus or a shared commitment.(PMBOK 2013)

\section{References}

[1]. Acharya, N. K., Lee, Y. D., and Im, H. M. (2006). Conflicting factors in construction projects: Korean perspective. Eng. Construct. Architect. Manage, 13(6), 543-566.

[2]. A Guide to The Project Management Body of Knowledge (PMBOK® Guide) Fifth Edition, Project Management Institute, Inc, (2013), Pennsylvania USA

[3]. Carmicheal, D.G.(2002). Disputes and International projects, A. A. Balkema, Liise.

[4]. Dipohusodo. (1995), Project Management, Kanasius, Yogyakarta.

[5]. Dulaimi, M. F., Ling, F. Y. Y., and Bajracharya, A. (2003). Organizational motivation and inter-organizational interaction in construction innovation in Singapore. Constr. Manage. Econ, 21(3), 307-318.

[6]. Fenn, P, Lowe, D., and Speck, C.(1997), Conflict and dispute in construction - Contract Management Economics, Journal of Management in Engineering, ASCE, 18 (1:20)

[7]. Hall, J, M.(2002), Ineffective Communication : Common Cause of Construction Disputes, Alliance'sAdvisory Council Legal Notes. 13(2).

[8]. Harmon, K. M. J. (2003). Conflicts between owner and contractors: Proposed intervention process. J. Manage. Eng. 3(121), 121125.

[9]. Jehn, K. A., and Bendersky, C. (2003). Intragroup conflict in organizations:A contingency perspective on the conflict-outcome relationship. Res. Organ. Behav., 25, 187-242.

[10]. Kissiedu, A.(2009), The Development ofAppropriateStrategiesfor The PreventionofConstruction Disputes In Ghana, Master ofthesesKwane Nkrumah University OfSciencesAnd Technology, Ghana.

[11]. Kumaraswamy, M. M. (1997). Conflicts, claims and disputes in construction.Eng. Construct. Architect. Manage, 4(2), 95-111.

[12]. Kumaraswamy, M. and Yogeswaran, K. (1998). Significant sources of construction claims , International Construction Law Review, 15 (1).144-160. 
[13]. Leung, M., Liu, A. M. M., and Ng, S. T. (2005). Is there a relationshipbetween construction conflicts and participants satisfaction? Eng. Construct. Architect. Manage., 12(2), 149-167.

[14]. Leung, M., Ng, S. T., and Cheung, S. O. (2002).Improving satisfaction through conflict stimulation and resolution in value management in construction projects. J. Manage. Eng.2(68), 68-75.

[15]. Maloney, W. F. (1990). Framework for analysis of performance. J. Constr. Eng. Manage. 3(399), $399-415$.

[16]. Ock, J. H. and Han, S. H.(2003). Lesson Learned form Rigid Conflict Resolution in an Organization: Construction Conflict Case Study, Journal of Management in Engineering, April 2003.

[17]. Poerdiyatmono, B.(2007), The Alternative Dispute Resolution of Construction Services, Journal of civil Engineering, University of AtmaJaya, 8(1).

[18]. Robbins, S. P., and Judge, T. A. (2009). Organizational behavior, 13th Ed., Pearson Education, Prentice Hall, NJ.

[19]. Ranupandjojo, H, and Husnan, S.(1994), ManajemenPersonalia, BPEE, Yogyakarta.

[20]. Soeharto, I2001,Project Management, Erlangga, Jakarta.

[21]. Syah, M 2004, Tips for Successful Managers, BinapuraAksara, Jakarta.

[22]. Susila, H. (2012). Causes of Conflict in the Implementation of Project Construction, Journal of Engineering and Architecture, Faculty of Engineering, University of Surakarta Tunas Development, 11(15).

[23]. Yiu, K. T.W. and Cheung, S. O. (2006). A catastrophe model of construction conflict behavior. Build. Environ. 41(4), $438-447$. 